\title{
East and West in Zakia Khairhoum's the End of My Dangerous Secret
}

\author{
Youssef EL KAIDI \\ Faculty of Arts and Humanities, Sais-Fes, Fes, Morocco \\ Youssef.elkaidi@usmba.ac.ma
}

DOI: http://doi.org/ 10.36892/ijlls.v3i4.726

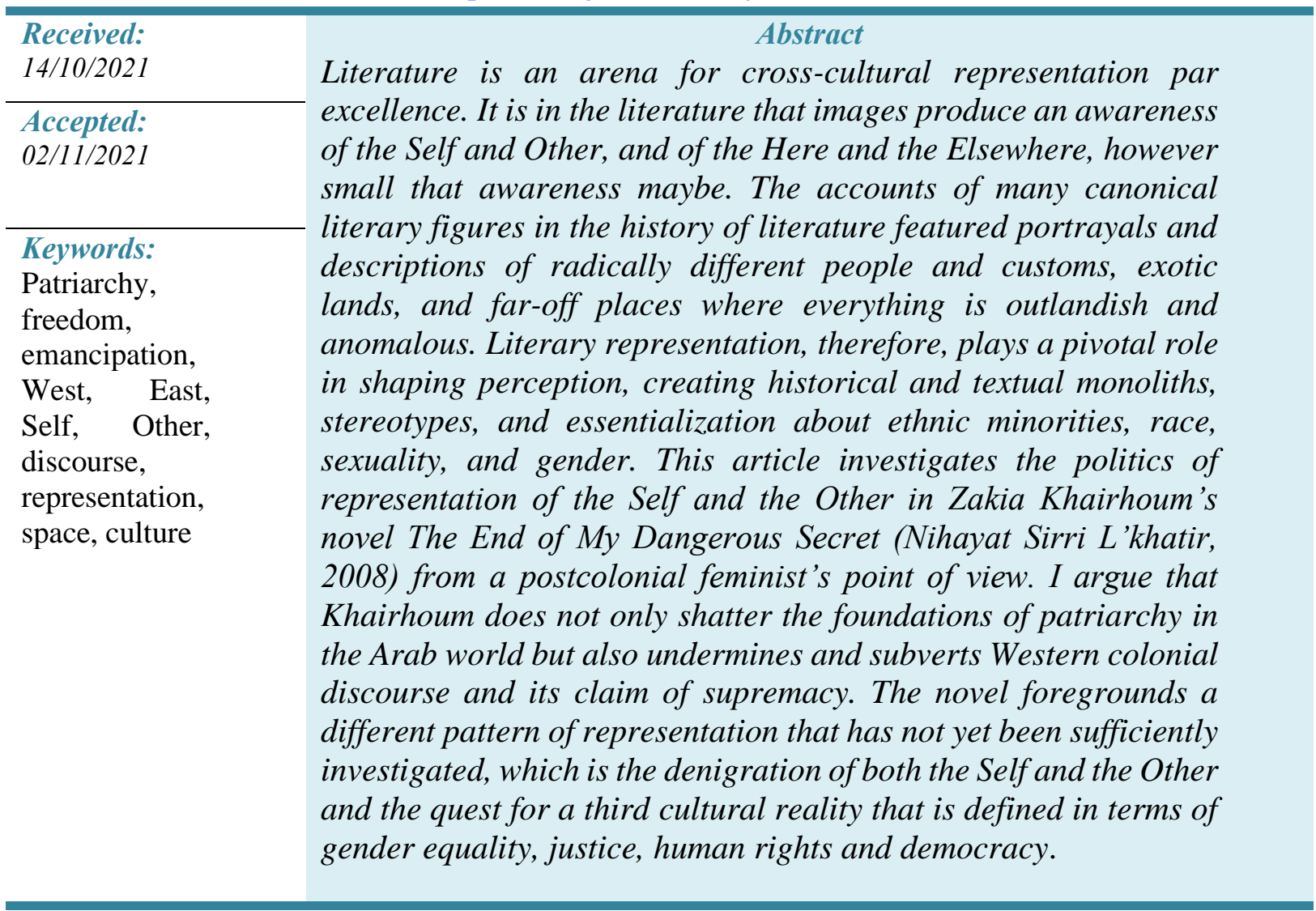

\section{INTRODUCTION}

\subsection{The End of My Dangerous Secret: Synopsis and Critical Reflection}

The End of my Dangerous Secret is an audacious work by the Moroccan expatriate in Norway, Zakia Khairhoum. Written to deconstruct and critique the patriarchal and misogynistic foundations of the Arab culture, the novel recounts the experience of Ghalia, the protagonist and the undoubted persona for the writer herself, who mistakenly believes she had lost her virginity after finding bloodstains on her underwear when she was playing as a child. The nightmare of not being a virgin anymore, given the importance of virginity in Arab societies, has haunted her since she was seven years old, usually causing her traumatic psychological and mental distress, especially when she thinks of marriage. To escape her apprehensions, she devotes herself to the pursuit of education, wishing never to graduate and get married because, to her mind, marriage represents death.

Born in Morocco to a Mauritanian father and a Sudanese mother, Ghalia represents the plight of all Arab women under the myriad of cultural practices that relegate women to a 
secondary creature who is domineered and controlled by man, and, above all, by the deeprooted man-constructed cultural traditions. The novel exposes the gruesome practice of female circumcision, honor killings, the myths around virginity, social and familial hypocrisy with regard to women, gender inequality, and sexual harassment. The amount of criticism leveled against Arab societies at The End of my Dangerous Secret attests to the writer's intellectual depth and grasp of the complexities characterizing Arab societies. The experience she dramatizes in her novel is personal and real as she declares at the very beginning of her book.

Ghalia's high performance at school gains her a scholarship to an American university. She then lives for one year with an American host family, but this initial travel is of very little importance to the narrative to the extent that the author recounts almost nothing about it. It is only after her second travel to America ${ }^{i}$ that Ghalia unveils her perceptions of this Western society. After returning from her initial travel to America, Ghalia wants to escape Morocco again lest her family enforces marriage on her. Fortunately for her, her father's Libyan friend convinces the family to take her to Libya where she can enroll at a Libyan university. On the long overland trip to Libya across the Algerian desert, Ghalia discovers that her father's friend, though ostensibly pious and polite, is but a wolf in sheep's clothing who wants to molest her and rob her of her money. However, the intervention of Samir, a young educated, and the seemingly liberal man who is on the same trip to Libya, would be decisive to save Ghalia from the old man. The way Samir treats her and the amount of warmth and protection he engulfs her with makes her easily fall in his love, yet she keeps her emotions under ashes because of her dangerous secret. How would he react if she reveals her secret to him? What would he do? After hesitation and indecision, Ghalia eventually confides in him, thinking that he would be understanding and sympathetic, especially after showing liberal attitudes and support for women's rights. To her disappointment, Samir shows no sympathy or understanding whatsoever, claiming that his advocacy of women's rights does not mean he accepts impurity and unchastity.

Emotionally wrecked, Ghalia resumes her quest for meaning in a world that rejects her for a 'sin' she did not commit. She wanders purposelessly in the streets of Tripoli dragging behind all the woes and agonies her virginity caused her and trying to dismiss the questions and uncertainties haunting her mind. Her life eventually becomes at great risk in Libya after a gang starts tracking her for refusing to yield to the sexual desires of their boss. To escape death which seems to chase her wherever she goes, she travels overnight to Morocco with the help of her Libyan friend, Nabil. However, the moment she sets foot in Morocco, her father starts enforcing marriage on her, claiming that the right place for a grown-up girl is her husband's abode. As soon as Nabil knows of her dilemma, he comes from Libya and proposes to her, yet the marriage would be faked to save Ghalia from her society and family. At the wedding night, Nabil cuts a wound in his arm and rubs the blood with a piece of white cloth to prove her chastity and save her honor; an act that speaks volumes of the credulity of some aspects of the Arab culture and how easily it can be ridiculed and laughed at. Relieved of the nightmare she has been living with, Ghalia travels with Nabil to Libya and after a few days, they fly to America. After making sure that Ghalia is well-settled, Nabil decides to end his role as a savior at this point of the narrative and withdraws from her life forever.

To make ends meet in America, Ghalia works part-time as a waitress in a Lebanese restaurant where she meets Adil; a Norwegian of Lebanese origin who falls in her love only after a few meetings. In a routine medical test, she discovers that her virginity is still intact and that the nightmare of honor killing she has been living with was but an illusion that completely ruined her life. To take revenge on the obsolescent regressive traditions and the patriarchal culture in her society she determines to remove her virginity before marriage, pledging that any man who wants to marry her should marry her for what she is not for a few little drops of blood. Adil accepts her condition and understands her plight. They eventually marry and decide to live in Norway. 


\section{East and West in Zakia Khairhoum's the End of My Dangerous Secret}

In a nutshell, the plot of the novel is rich in its settings and events as well as in its daring approach to the deconstruction of the regressive patriarchal practices in Morocco and the Arab world as a whole. The novel might be violently shocking to the Arab reader who is not used to such explicit discussion of the taboo of the hymen; this thin membrane for which many female lives have been taken in the Arab world under the pretext of honor. The overall story is characterized by the existence of other sub-stories or underplots with distinct characters, settings and events allowing the author to explore a range of issues with regard to gender, identity, history, culture, Self and Otherness.

\section{America as the Epitome of Freedom}

The protagonist's quest for personal freedom takes her through an itinerary of multiple trajectories: America, Libya, Morocco, America again, and finally Norway. Ghalia's perturbing dangerous secret is the driving force behind her constant quest for safety and security and any place away from her conservative parents could be a safe haven. What is important at this juncture is Ghalia's second travel to America and her sentiments towards this Western society since only a few details are given in the novel about her first one-year residence with an American host family. The image of America in prior literary works by Arab writers takes many forms and manifestations, attesting to the plethora of Arab representations of this Western society. Ever since the Arabic Cultural Awakening (Nahda), America has been portrayed as the unchanged Other, the seductive female, the example to emulate, the source of all evil, the land of contradictions and appearances, the hub of immorality and decadence, the enemy of Islam and Muslims, and the epitome of freedom and democracy. ${ }^{\text {ii }}$

After Ghalia's homecoming from a one-year stay in America, the dream of returning back and continuing her studies at a distinguished American university preoccupied her mind to the degree of obsession. In America, she would be safe distances away from her society that she repeatedly describes as the desert of ignorance and backwardness. In America, she would be free of the continuous impositions of her father and the constant nagging and physical abuse of her mother. Above all, in America, she can start building her future away from dependency and tradition that sickens her. She states "I want to build up my future away from dependency and tradition." (Khairhoum, 2008, p. 96). Her father holds very radical anti-American views which he always uses as a pretext to prevent her from traveling back again. When she mentions America, he angrily reacts: "America! America! I do not know what impresses you in that country. It is the land of moral dissolution, crime and terrorism." "iii (Khairhoum, p. 215). Yet, Ghalia maintains an eclectic attitude towards cultural otherness. To her, not all that is Moroccan is good, nor all that is American is evil. She affirms: "I do not consider America an ideal society. I do not, however, consider it the land of wickedness and corruption either. Wickedness is everywhere in the world." (Khairhoum, p. 215) Unlike the disparaging perception of America expressed by her father, Ghalia's thoughtful attitude reflects a critical deconstructive stance towards her own culture and towards otherness. Otherness, for her, can exist at home where she feels she does not belong. Her Other is the conservative culture that subjects women to inhumane and regressive practices such as female genital mutilation, honor killing, docility and blind obedience to the husband and the father, female sexual enslavement and other similar misogynistic practices. Therefore, leaving her country and her family becomes her ultimate goal: "My heart palpitates with freedom and the desire to leave those homes which are submerged in the mud of backward habits they attach to religion and carry their banner under the slogan of Islam." (Khairhoum, p. 62) The sense of insecurity, uprootedness and alienation inhabiting and inhibiting Ghalia is due to her culture which made her stagger into the arms of the unknown in Libya where her plight becomes even more perilous. Nabil warns her: "You will start working in this country [meaning Libya]. You have to be very careful. Going out alone is forbidden. Here, girls and women get raped and burnt on a daily basis." (Khairhoum, p. 141) Libya, therefore, is no different from Morocco since both societies are historically shaped by the same religious and cultural parameters, and women's position in this society is 
even worse. America, accordingly, becomes Ghalia's dream society. Right before the plane takes off to New York in her second journey to America, Ghalia expresses her intense rapture at her long-awaited emancipation from the society of women's enslavement, defunct traditions, and backwardness. She says:

It was time for the plane to take off to Rome and from there to New York. I did not know whether I was daydreaming or I was actually on my way to America where I would be away from the obsession of grooms in Morocco and the cuffs that shackle the soul and strangle it [...] I am now on my way to freedom. (Khairhoum, p. 318)

This attitude is crucial in determining Ghalia's conception of America prior to her actual arrival and living in this society. To a suffering woman like her, escaping a conservative environment to a liberal country like America would be synonymous with emancipation, freedom, and selfdetermination. It is noteworthy here that the narrative point of view fluctuates from the anonymous third-person narrator to the first-person perspective every time Ghalia travels out of Morocco, suggesting that her voice is smothered and silenced at home and only comes back after she is away. Shifting to the first-person narration immediately after Ghalia starts her journey to America is a strategy by which the author gives Ghalia her agency/authority back after she was stripped of it by her parents and society at home. The reader feels that she does exist with full ownership of her voice, assertively speaking out against oppression and building trust with them. The journey to America, therefore, is emancipatory in the sense that it allows Ghalia to tell her story from an empowering perspective. Lamenting her plight to the Statue of Liberty from the window of her hotel room overlooking the famous monument, she says:

I finally came to you, $\mathrm{O}$ freedom. Finally, the heavens helped me to come out to you like a princess from her prison, leaving behind ornaments and jewelry, and servants and assistants; leaving behind my family and my tribe. I wanted nothing but my right and I did nothing but my duty. I flew to you with my wings. My heart adores you and my eyes are eager to behold you. (Khairhoum, p. 320)

The happiness enveloping Ghalia following her travel to America is unmistakable and so is her first shock at and fascination with the American affluence. She describes everything she sees with awe and amazement evoking Quranic terminology used to describe paradise such as "an outspread carpet and lined up cushions." (Khairhoum, p. 321) America appeared to be, thus, as beautiful as a paradise to Ghalia even in its smallest details. She states:

[There are] towering glass edifices and spacious rooms, each leading to the other. I am surprised at their width and large size. They are filled up with countless and immeasurable things, things of miraculous beauty and exciting trappings.... distant world... strange... terrible... magnificent... scary. There is a high sofa in the room, a spread-out carpet, and lined-up cushions. I turned my sight again to the street [...] contemplating that lifestyle and the difference and disparity between my society and this society to which I have longed to return. I surveyed with my eyes from that vantage point where I was standing, pondering those giant skyscrapers and that sophistication in luxury. (Khairhoum, p. 321)

The lexical items Ghalia deploys in her description of America reflect her profound cultural shock at this society which evoked unexplainably and mixed up emotions in her, and whichcompared to hers- is strange, giant, affluent, and scary. The high point of view- the panoptical position- she occupies vis-à-vis New York- the object of her gaze- allows her to see this hectic 
city as a theatrical show, spectacle and performance. It is only after this surveying gaze that Ghalia begins to realize her difference and grows increasingly self-conscious. In this regard, David Spurr argues that "to look at and speak to not only implies a position of authority; it also constitutes the commanding act itself." (14). Therefore, Ghalia's position in her high hotel room subverts the colonial position of a privileged point of view recurrent in colonial discourse. After her first positive attitude of America, one is compelled to wonder whether she will maintain the same perception of this country or this attitude will change after she observes and scrutinizes it from within.

\section{America and the Illusion of Freedom}

In the preceding section, I demonstrated how Ghalia perceived America as the epitome of freedom and emancipation. The Statue of Liberty, the symbol of liberalism and democracy, became the source from which she draws power and to which she laments her woes and agonies. Her initial encounter with the American society, hence, was marked by a fascination with and shock at the development, material achievements, and luxurious affluence of Americans. Yet, this positive perception of America is short-lived. The more Ghalia digs up for freedom in American society, the more it eludes her like a mirage. The Statue of Liberty appeared helplessly surrounded by water from every corner like a convict. This stupendous monument, which is used as a metonymic symbol in the novel, is hailed as the most potent and immediately recognizable symbol of New York City- and, indeed, of the United States. "Reproduced romantically, satirically, patriotically, defiantly, or as a parody; the image of a woman holding a torch and clutching a tablet has seeped into the public imagination, worldwide, to represent the United States and its claim to uphold liberty," as Michelle Hartman notes. (401)

Like many other Arab writers, Khairhoum uses the symbolic importance of the Statue of Liberty for protest and contestation against the corrupt system of values she discovers in America. New York, and all America by implication, is just as helpless, lifeless, unnatural and completely passive as the Statue of Liberty which is deaf to Ghalia's continuous pleas for freedom. Therefore, New York, the city of lights and lofty towers, appeared to her like an arid desert (بيداء) after only a week in it. This sudden unexpected change in Ghalia's attitudes towards America is, somehow, concomitant with the breakdown of her second love story with Nabil who left her and traveled back to Libya. After his unconditional sacrifices for her and his platonic love, Ghalia loved him madly in turn but their love came to a deadlock after she realized that he is married and father to many children. Worse than this, he does not know about her 'dangerous secret.' Heartbroken, she cries inconsolably: "I love you... I love you so much...I do not want anyone except you... but you, like all other men, are eager to penetrate a woman through her hymen, which I do not have." (Khairhoum, p. 329). It is crystal clear, thus, that many of Ghalia's attitudes are a projection of her own inner psychological state and painful personal experience. She colors her outside world with the colors of her inner psychological mood. Escorting Nabil to the airport, Ghalia stops by the Statue of Liberty again blaming it for her failure. She angrily says:

What is the matter with you, $\mathrm{O}$ freedom, standing high encircled by water like in prison, raising in your hands the victory symbol? What symbol are you raising and what victory are you singing to? True freedom is never limited to symbols, and it never rests on fictitious intentions and fake promises. True freedom manifests itself in people's daily practices and relationships dictated by the nature of society which is based on sound democracy to face defeat and overcome it and its causes. I came to you flying across the seas but you neither consoled me nor helped me face my defeat against the knight of my love and dreams. (Khairhoum, pp. 331-332) 
The failure of Ghalia's love affair does not only deepens her suffering and feeling of alienation in America but also helps reshape her perception of this Western society where people are devoid of compassion. New York streets feel to her "lonelier and scarier than the streets of Tripoli." (Khairhoum, p. 332) She talks about her wandering and loss in the "desert" of New York and the need to escape America, the country which no longer appeals to her. She states: "I am lost in the desert of New York and in the streets of the desert of New York. I must leave this country." (Khairhoum, p. 355) The ideal image Ghalia painted of the American society is proved to be completely wrong as she intermingles with people and observes the flagrant contradictions and the social ailments plaguing Americans. She realizes that her quest for freedom in America is a forlorn attempt because Americans themselves need to be freed. They are enslaved by their materialistic culture and capitalist economy which promote all sorts of moral delinquency, crime, social inequality, and injustice. Khairhoum seems to tell us that the American people and the Moroccan/Arab people are both enslaved by their cultures and, thus, the superiority of America is but a figment. America, Ghalia asserts, is a hypocritical society living under fake disguises and colorful deceptive masks. It is a jungle-like society where the survival is for the richest and the most powerful. She states in this regard:

I see people rushing to their workplaces at lightning speed; some eating while walking. They do not even have time to take their breakfast at home. Others walking almost naked, their bodies tattooed in signs, slogans and obscene pictures. A young man hugging and kissing another man on the sidewalk. A young girl hugging and kissing another girl on the lips. Another group of young men and women wearing leather black clothes, their hair is cut except for some hair lined up in the form of cockscomb and dyed in bright colors. Some people dress in fancy clothes and live in luxurious houses, others wear worn-out dirty rags and live in cardboard boxes in the streets. [There are] huge lofty buildings scratching the clouds next to old dirty underground houses. (Khairhoum, p. 388)

The scenes of contradiction and decadence above profoundly struck Ghalia and broke her ideal preconception of American society. New York, and all America by extension, is hellish in the eyes of Ghalia. Her feelings of compassion for the inhabitants of this monster city mingle with the feelings of hostility towards their customs, culture and way of life. She states:

I ambivalently felt enmity and compassion for them at the same time. They live in New York, in America, in hell, in the world of faked freedom, in a giant illusion, dollar, luxury, speed, fraudulence, murder, robbery, theft, racism, drugs, pornography, and explicit sex. This is American freedom and civilization. ( Khairhoum, p. 388)

The freedom she heard about, believed in and desperately flew to after years of despair in her country was an illusion. The amount of violence she witnesses in New York; particularly, the incident of the stabbing of her friend Lucho before her very eyes in the restaurant where both have part-time jobs impacts her so profoundly. The story of Ghalia's friend, Engel, who was savagely raped and photographed to blackmail her father who was running for state senate also deepens Ghalia's sense of insecurity in New York. Thus, the concept of freedom the West boastfully brags about appears to Ghalia deceptive and elusive. Therefore, she frustratingly ponders:

Is this the society I have been dreaming to come to, and of which I have painted an ideal image in my mind? What is ideal about this society? What I see is but savage capitalism looting the weak with its claws and crashing them under its hooves. This 
freedom is only the freedom of worldly passions and desires that are lacking even in animals. The freedom of beasts and wolves...This is manifest strife in this America... No justice, no fraternity, no equality and no security. (388)

Ghalia's disillusionment with American society and its way of life springs from the drastic cultural differences between her culture and the American culture. Her religious and cultural background- or her imagined self as an Arab and Muslim interferes against the scenes of homosexuality, lesbianism, and all the forms of what she calls blatant immorality. Freedom to her is way beyond the freedom of corporeal desires and animalistic passions. Freedom, she believes, can never be achieved as long as the human mind and its cognitive abilities are disrupted in favor of primitive urges, desires and whims. In this regard, she states: "Freedom cannot and will never be achieved as long as the human [American] mind is veiled. Freedom is noble behavior, and humane conduct." (Khairhoum, p. 338) This attack on the American mindset which is conceived as being intolerably corrupt goes in line with Buruma and Margalit's observation that:

The attack on the West is among other things an attack on the mind of the West. The mind of the West is often portrayed by Occidentalists as a kind of higher idiocy. To be equipped with the mind of the West is like being an idiot savant, mentally defective but with a special gift for making arithmetic calculations. It is a mind without a soul, efficient like a calculator, but hopeless at doing what is humanely important. (Khairhoum, p. 75)

It is indeed the missing human aspect that Ghalia's criticizes in the American mindset. Her disparagement of the American society, therefore, goes to the extent of animalizing it and stripping it of its moral rationality when she compares hankering after degenerate material pleasures to beasts and wolves. By criticizing the American society in terms of its materialism and moral decadence, Khairhoum is reinscribing and reaffirming the old axiom of Western materialism and moral decadence compared to Eastern spiritualism and moral transcendence found in many early Arabic texts. In a pan-Arabism discourse, she asserts that the Arab nation would be the best nation on earth if it had transparent and clean leaders. She says:

Oh my big nation! Oh my Arabism and my Islam! If the rulers of our bigger home... The rulers of this Arab nation [...] understood justice, ruled with it, spread it and cooperated for it, not for power and privilege, we would truly become the best nation sent to mankind. (Khairhoum, p. 339)

Obviously, Khairhoum ascribes Arab stagnancy and backwardness in matters of material and scientific development to the lack of justice and the prevalence of corruption among Arab rulers though their legal and cultural systems are highly informed by theology and spirituality. The West, in contrast, is ruled by democratic leaders who are loyal to their countries and fellow citizens despite the fact that they lack spiritual, mystical, or theological principles. Thus, the ontological question earlier Arab and Muslim travelers in the West pondered of "why is the West way advanced while the East is still wallowing in its stagnancy?" continues to baffle Khairhoum as well. She writes about her protagonist and unmistakable persona:

[She sat for] long hours thinking and pondering about her customs and theirs, her traditions and theirs. Why are we dependent while they are productive? Why are they progressive while we are regressive? This West is able to take us back to the Stone Age if it stops the exportation of its products and industry to us. Even our holy Quran is printed by Western printing machines. Even for bread, most of our 
countries depend on American, Canadian, and Australian wheat. (Kharhoum, p.367)

In the passage above, Khairhoum reveals the bottomless abyss between the development of the West and the backwardness of the East. Nevertheless, her acute awareness of Western scientific and industrial miracles does not serve to diminish her disdain and disparagement of the West. Rather, it is meant to shake Arabs' trees and arouse them to work, innovate, produce and create to catch up with the speeding train of Western development. Her attitudes towards the West in general and America, in particular, grow uncompromisingly hostile as the narrative develops. The use of the equivalent of the definite article 'the'- which is 'ال' in Arabic- for America in many occasions in the novel is meant to express disdain and scorn, knowing that 'أمريكا' (America) in Arabic never takes the definite article 'ال'. In such cases when the 'ال' is used, it connotes ridicule and cynicism. This stylistic maneuver enables the novelist to impart her belittlement of America, implying that this America is nothing, it has no value, and it is in no way superior to us/the Arabs if it is not rather inferior.

The quest Ghalia launches for freedom comes to a deadlock as she lives in New York and carefully surveys its minute details. The secret she has been covering continues to torment her, especially at the thought of going back to Morocco despite the overwhelming nostalgia she feels for her country and her loved ones. Yet a turning point in the novel would be the unexpected meeting with a Lebanese man who would utterly change her life and her perception of herself and the world. Adil is the only person who manages to rescue Ghalia and relieve her of the vicious circle of hallucinations, nightmares, phobia, and paranoia her childhood incident caused her. For accepting and loving Ghalia for her character and personality per se and for considering her an equal human being, not a mere female, Adil becomes synonymous with freedom. He takes the position, the height, and the glamour of the actual Statue of Liberty which has hitherto been helpless for her plight despite her continuous pleas for its help. She addresses Adil:

Are you the Statue of Liberty? Is it you? Is...

He smiled and said: I am freedom itself... I am true love and nobility [...]

She cheered up and embraced him to her chest and said: You are freedom... Yes, you are free. I recognize you...Come on, I want to go with you, fly with you in your life and dreams and make them part of my dreams and life. (Khairhoum, p. 381)

With this turn in the plot, we learn that Ghalia's quest for freedom is fulfilled. The freedom which eludes her in Morocco, in Libya and in New York is finally found in an educated, openminded, brave, generous, and kind-hearted man, as she describes him. New York, and by implication all America, is represented as a country that is fraught with violence, hypocrisy, moral decadence, and lack of virtue. This representation reverses the supremacy of Western values and undermines the stereotype that America is the cradle of dreams, personal achievements, limitless possibilities, freedom, egalitarianism, and democracy. By so doing, Khairhoum is leveling a conscious critique against the hegemonic tendencies in the American political and cultural discourses, appropriating and deploying the very discursive strategies common in colonial discourse. Lhoussain Simour (2010) eloquently states in this regard that

The marginal creates a space that allows for resistance to and subversion of the Western hegemonic discourse. The protagonist, the author [herself], assumes authority and acquires agency engaging in a political act of "writing back" in order to reverse the historically established Western modes of representation that operate along with the parameters of inclusion and exclusion. (pp.39-40). 
Kharihoum's mission, as a post-colonial writer, is "to recover and reclaim [her] lost identity, and to recuperate, reinvigorate and free [her] dominated culture." (Jorge, 2019, p. 73) Therefore, she assumes what Simour calls "agency" and "authority" which allow her to scrutinize, analyze, and criticize the American society and its values. By so doing, she actively asserts not only her cultural and ethnic identity as an Arab, but also her gender identity as a woman who reclaims her voice and undertakes the thorny issues of gender and cross-cultural representation.

\section{CONCLUSION}

With her unmistakable postcolonial feminist ideological background, Khairhoum dismantles not only the historically established Western modes of representation but also the dominant discourse of patriarchy. The novel, therefore, is an attempt at decolonizing Arab and Moroccan women from the double colonization of cultural patriarchy and Western colonialism by subverting both discourses and rendering them completely vulnerable. Ghalia's quest for freedom leads the reader to discover a new pattern of cultural representation, which is the denigration and disparagement of both the Self and the Other and the search for a third utopic cultural reality that guarantees freedom, gender equality, justice and democracy. This reality, Ghalia realizes, exists neither in Morocco and the Arab world at large, nor in America because both cultural extremes are fraught with inequality, oppression, and injustice. However, the novel comes to its ending without telling us whether Ghalia found this third reality or not. This open ending is suggestive of the different possible scenarios for the unresolved major conflict, which is Ghalia's quest for freedom. It perhaps reflects the writer's cynical belief that this dream-reality that guarantees freedom, equality and justice to all is our responsibility to foster and promote for future generations.

\footnotetext{
Notes

'The use of 'America' here and throughout this article instead of 'The United States of America' is done to correspond with the author's consistent use of أمريكا (America) in her novel, instead of الولايات المتحدة الأمريكية (The United States of America)

ii For more details on Arab representation of America, read America in an Arab Mirror, edited by Kamal Abdelmalek and Mouna El Kahla, and Rasheed El Enany's Arab Representation of the Occident.

iii Unless otherwise indicated, all translations are mine.
}

\section{REFERENCES}

Buruma, I., \& Margalit, A. (2004). Occidentalism: The West in the Eyes of its Enemies. New York: The Penguin Press.

Hartman, M. (2005). Writing Arabs and Africa(ns) in America: Adonis and RadwaAshour from Harlem to Lady Liberty. International Journal of Middle East Studies, 37(3), 397-420. https://doi.org/10.1017/S002074380505213X

Jorge, R. (2019). Postcolonial Discourse and the Irish Self in the Writings of J.S. Le Fanu. International Journal of Language and Literary Studies, 1(3), 71-84. https://doi.org/10.36892/ijlls.v1i3.60

Khairhoum, Z. (2008). Nihayat Sirri al-Khatir. Rabat: Dar Abi Rakrak.

Simour, L. (2010). New York through Moroccan Eyes: (Re)/Disorienting Orientalism American Style. Journal of Post-Colonial Cultures and Societies. 1(2), 22-45. Retrieved from 
https://zdocs.tips/doc/1137127834new-york-through-moroccan-eyes-mpvywekmwjp3 $\quad$ on October 12, 2021.

Spurr, David. (1993). The Rhetoric of Empire: Colonial Discourse in Journalism, Travel Writing and Imperial Administration. London: Duke University Press.

\section{$\underline{A U T H O R ' S B I O}$}

Youssef EL KAIDI is a professor of English Literature and Cultural Studies at the Faculty of Arts and Humanities, Sais-Fes, University Sidi Mohamed Ben Abdellah, Fes, Morocco. He obtained a doctorate degree in Cultural Studies from the Dhar Mehraz Faculty of Letters and Human Sciences in Fes in 2017. Beyond his academic interest areas of literature, cultural studies, translation and cross-cultural communication, Youssef takes great interest in journalism and has written extensively on political, cultural, historical and social issues in Morocco and the Arab World. Youssef has participated in many international summer schools and teacher training events, visiting globally renowned universities in the United States, Germany, and Japan. 